\title{
Analisis Penggunaan Antibiotik pada Pasien Sepsis Neonatus di RSUD Arifin Ahmad Provinsi Riau
}

\author{
Nazardi Oyong, ${ }^{1}$ Inayah, ${ }^{2 *}$ Yuni Novita, ${ }^{3}$ Rizki Giofani ${ }^{4}$
}

\begin{abstract}
Sepsis that is commonly caused by bacterial infection may cause death in neonates. The appropiate antibiotic administered will increase the life expectancy of neonates with sepsis. Objective of this study was to know the pattern of antibiotic use and appropriateness of antibiotic use based on sensitivity test. The study used observational method with cross sectional design. The collected data were retrospective. The study population were neonates with sepsis in perinatal ward from Januari - December 2014. The criteria of inclusion were positive blood culture with sensitivity tests and use of antibiotics. The percentage of particular antibiotics used in neonates with sepsis before sensitivity test were amikacin $64,3 \%$; meropenem $62,9 \%$ and piperazine/tazobactam $50 \%$ with suitability of $27,1 \%$. However, after sensitivity test there were meropenem $38,6 \%$, amikacin $30 \%$, vancomycin $14,3 \%$ and piperaciline/tazobactam $14,3 \%$ with appropriateness of $64,3 \%$. The most number of antibiotic used before and after sensitivity test were amikacin and meropenem, respectively. There was a suitability enhancement between the use of antibiotics and sensitivity test results.
\end{abstract}

Keywords : antibiotic, neonates, sensitivity test, sepsis.

Sepsis neonatus merupakan istilah yang lazim digunakan untuk mendeskripsikan respons sistemik terhadap infeksi bayi baru lahir. Sepsis neonatus yang dikenal juga dengan istilah septikemia atau sepsis neonatorum, merupakan suatu sindroma klinik penyakit sistemik disertai dengan bakteremia yang terjadi dalam bulan pertama kehidupan yang dapat mengenai 1-5/1000 kelahiran hidup. Angka kejadian sepsis pada neonatus cukup tinggi pada negara berkembang. Terdapat 18 kasus pada setiap 1000 kelahiran jika dibandingkan dengan negara maju yang berkisar antara 1 sampai 5 kasus pada setiap 1000 kelahiran. ${ }^{1-3}$

Kematian pada neonatus terutama disebabkan oleh sepsis, yaitu lebih dari satu juta kematian neonatus di seluruh dunia setiap tahunnya. ${ }^{1,4,5}$ Menurut World Health Organization (WHO),

\footnotetext{
* Penulis untuk korespondensi : umiadya@yahoo.com ${ }^{1}$ SMF Anak RSUD Arifin Ahmad Pekanbaru

${ }^{2} \mathrm{KJF}$ Farmakologi Fakultas Kedokteran Universitas Riau

${ }^{3}$ Fakultas Kedokteran Universitas Riau
}

terdapat 10 juta kematian neonatus dari 130 juta bayi yang dilahirkan setiap tahunnya. World Health Organization juga memperkirakan dari lima juta kematian neonatus setiap tahunnya, negara berkembang menyumbang persentase hingga $98 \%$. Angka kejadian dapat meningkat mencapai $13-27$ kasus setiap 1000 kelahiran hidup pada bayi yang lahir dengan berat $<1500$ gram. ${ }^{1,2,4,5}$

Berdasarkan klinis sepsis neonatus diklasifikasikan menjadi sepsis onset dini (earlyonset sepsis/ EOS) dan sepsis onset lambat (lateonset sepsis), dan onset paling cepat dapat terjadi pada bayi prematur. ${ }^{6}$ Sepsis onset dini terjadi antara 24 jam sampai 6 hari, terbanyak terjadi dalam 72 jam setelah kelahiran. ${ }^{7}$ Penulis lain mengatakan terjadi pada 5-7 hari pertama kehidupan. ${ }^{3}$ Mikroorganisme penyebab sepsis onset dini paling banyak adalah Streptococcus Grup B (43\%) diikuti Escherichia coli, (15,5-29\%) sedangkan pada bayi berat badan sangat rendah lebih banyak disebabkan oleh Escherichia coli dibanding Steptococcus Grup B. ${ }^{8}$

Sepsis onset lambat terjadi lebih dari 72 jam setelah kelahiran. Sepsis lambat mudah menjadi 
berat, tersering menjadi meningitis. Bakteri penyebab sepsis dan meningitis, termasuk yang timbul sesudah lahir yang berasal dari saluran genital ibu, transmisi horizontal dari kontak antar manusia atau dari alatalat yang terkontaminasi. ${ }^{3,7,9}$ Bakteri penyebab sepsis onset lambat paling banyak ditemukan diantaranya bakteri Gram positif sebesar $49 \%$ diikuti Staphylococcus koagulase negatif sebesar $45 \%$, sedangkan bakteri Gram negatif lebih rendah yaitu sebesar 23\% namun berhubungan dengan mortalitas yang lebih tinggi di neonatal intensive care unit (NICU) yaitu sebesar $19-36 \% .5,10$

Sepsis pada neonatus ini paling sering disebabkan oleh infeksi bakteri. Menurut Shrestha dkk. hasil kultur darah terbanyak berasal dari Gram positif yaitu Staphylococcus aureus dan Staphylococcus koagulase negatif. Sedangkan Gram negatif terbanyak adalah Klebsiella $s p$ dan Pseudomonas sp. Resistensi Klebsiella terhadap ampisilin sekitar $87,5 \%$, dan terhadap gentamisin $78,3 \%$. Di sisi lain, bakteri Gram positif pada umumnya resisten terhadap ampisilin sekitar 58,5\% dan gentamisin 31,5\%. Resistensi bakteri Gram negatif lainnya terhadap penisilin didapatkan $87,5 \%$, dan gentamisin $77,2 \%$. Kemudian, untuk uji resistensi terhadap sefotaksim didapatkan sekitar 87,34\% untuk Gram negatif dan 59,35\% untuk Gram positif. ${ }^{11}$

Berdasarkan hasil penelitian di RSUP H. Adam Malik Medan diperoleh hasil bahwa sepsis pada neonatus dominan dialami oleh bayi laki-laki sebanyak $54,4 \%$ dan bayi prematur sekitar $28,5 \%$ dari 239 bayi dengan sangkaan sepsis. Selain itu juga didapatkan data berdasarkan hasil biakan darah (hematogen) bakteri yang paling sering menjadi penyebab infeksi yaitu Staphylococcus sp, Pseudomonas $s p$ dan Enterobacter sp. Bakteri-bakteri tersebut masih sensitif terhadap vankomisin, amikasin dan meropenem, dimana vankomisin khusus digunakan untuk terapi antimikroba bakteri Gram positif. Vankomisin menjadi antibiotik yang paling sensitif (khusus bakteri Gram positif) pada tahun 2008 dan 2009, sedangkan amikasin merupakan antibiotik yang paling sensitif pada tahun $2010 .{ }^{1}$

Sepsis pada neonatus ini memerlukan penanganan yang tepat dan efektif agar prognosis dapat menjadi lebih baik. Salah satunya adalah pemberian antibiotik empiris yang tepat dan diberikan dengan segera. Terapi antibiotik empiris diberikan berdasarkan pola kuman yang ada di suatu rumah sakit. Pola kuman antara suatu tempat dengan tempat lain berbeda-beda, dan berubah dari waktu ke waktu. Perbedaan pola kuman ini akan mempengaruhi pemilihan antibiotik yang akan digunakan pada pasien. Pemberian antibiotik yang tidak tepat pada pasien sepsis akan meningkatkan angka kematian dan kemungkinan komplikasi jangka panjang yang mungkin diderita pasien. Selain itu penggunaan antibiotik yang tidak tepat akan memicu terjadinya resistensi bakteri ${ }^{1,12}$

Masalah penggunaan antibiotik sudah berlangsung sejak lama, salah satunya adalah di ruang rawat inap intensif. Ruang perawatan intensif merupakan suatu unit pelayanan yang memberikan penanganan dan perawatan terhadap kasus-kasus dengan sakit kritis yang memerlukan pemantauan, tindakan dan terapi yang intensif pada pasien.

Rumah Sakit Umum Daerah (RSUD) Arifin Achmad adalah rumah sakit rujukan pemerintah utama di Provinsi Riau yang telah memilik ruang khusus untuk perawatan bayi yang dikenal dengan ruang Perina. Perina adalah suatu unit pelayanan intensif bayi termasuk bayi yang mengalami sepsis neonatorum. Pasien-pasien yang dirawat di ruang tersebut sering mendapatkan terapi antibiotik sehingga profil tentang pemakaian antibiotik di ruang perina sangat dibutuhkan.

Berdasarkan fakta tersebut, penulis tertarik untuk melakukan penelitian yang bertujuan untuk mengetahui karakteristik pasien sepsis neonatus, pola penggunaan antibiotik sebelum dan sesudah uji sensistifitas, serta untuk mengetahui ketepatan penggunaan antibiotik berdasarkan uji sensitifitas pada pasien sepsis neonatus di RSUD Arifin Achmad Provinsi Riau periode Januari - Desember 2014.

\section{METODE}

Jenis penelitian ini adalah observasional dengan rancangan deskriptif, potong lintang/cross sectional, pengambilan data dilakukan secara retrospektif. Populasi penelitian adalah pasien sepsis yang dirawat di ruang perina RSUD Arifin Achmad Provinsi Riau periode Januari - Desember 2014 dengan hasil kultur darah positif mengandung bakteri. Sampel penelitian ini adalah populasi yang memenuhi kriteria inklusi yaitu memiliki data karakteristik pasien (jenis kelamin, 
berat badan lahir, awitan sepsis), data hasil uji resistensi dan sensitifitas, dan data penggunaan antibiotik sebelum dan sesudah pemeriksaan kultur darah. Sedangkan kriteria eklusi adalah pasien yang pulang paksa. Subyek penelitian dikategorikan mendapatkan antibiotik yang tepat jika antibiotik sesuai dengan hasil uji sensitifitas.

Pengumpulan data dimulai dengan penelusuran data pasien sepsis yang dirawat di ruang Perina di Bagian Mikrobiologi Instalasi Laboratorium Patologi Klinik dan Bagian Rekam Medis RSUD Arifin Achmad Provinsi Riau. Selanjutnya dilakukan pencatatan data sesuai kebutuhan penelitian dengan menggunakan lembar kerja. Kemudian data tersebut disajikan dalam bentuk tabel distribusi frekuensi dan narasi.

\section{HASIL}

Pada penelitian ini didapatkan 93 neonatus yang di rawat di ruang Perinatologi RSUD Arifin Achmad Provinsi Riau memiliki kultur darah positif yang ditemukan data rekam mediknya. Selanjutnya sebanyak 70 subyek yang memenuhi kriteria inklusi dan eklusi. Separuh dari subyek berjenis kelamin lakilaki dan sebagian besar memiliki berat badan lahir kurang dari 2500 gram. Jika dilihat dari mula terjadinya sepsis, lebih dari separuh pasien sepsis neonatus tergolong sepsis onset dini. Secara lengkap karakteristik subyek dapat dilihat pada Tabel 1.

Tabel 1. Karakteristik pasien sepsis neonatus

\begin{tabular}{lcc}
\hline \multicolumn{1}{c}{ Karakteristik } & Frekuensi & Persentase(\%) \\
\hline Jenis kelamin & & \\
$\quad$ Laki-laki & 35 & 50 \\
$\quad$ Perempuan & 35 & 50 \\
Berat badan lahir (gram) & & \\
$<1500$ & 17 & 24,3 \\
$1500-2499$ & 23 & 32,9 \\
$\geq 2500$ & 30 & 42,9 \\
Onset sepsis & & \\
Dini & 42 & 60 \\
Lambat & 28 & 40 \\
\hline Total & 70 & 100 \\
\hline
\end{tabular}

Gambaran penggunaan antibiotik empiris pada neonatus sepsis ditunjukkan oleh Tabel 2. Antibiotik terbanyak digunakan secara empiris pada periode ini adalah amikasin $(64,3 \%)$ disusul oleh meropenem $(62,9 \%)$ dan piperasilin/tazobaktam sebesar 50\%. Sedangkan antibiotik paling sedikit digunakan adalah gentamisin dan seftriakson yaitu masing-masing sebesar $1,4 \%$.

Tabel 2. Penggunaan antibiotik empiris pada neonatus sepsis

\begin{tabular}{lcc}
\hline Antibiotik & Frekuensi & Persentase (\%) \\
\hline Amikasin & 45 & 64,3 \\
Meropenem & 44 & 62,9 \\
Piperasilin/tazobaktam & 35 & 50,0 \\
Metronidazol & 3 & 4,3 \\
Gentamisin & 1 & 1,4 \\
Seftriakson & 1 & 1,4 \\
\hline
\end{tabular}

Setelah adanya hasil uji sensitifitas antibiotik definitif yang banyak diberikan oleh dokter pada subyek secara berurutan adalah meropenem $(38,6 \%)$, amikasin (30\%), Piperasilin/tazobaktam (14,3\%) dan vankomisin (14,3\%). Tabel 3 menggambarkan lebih rinci penggunaan antibiotik definitif.

Tabel 3. Penggunaan antibiotik definitif pada neonatus sepsis

\begin{tabular}{lcc}
\hline Antibiotik & Frekuensi & Persentase (\%) \\
\hline Meropenem & 27 & 38,6 \\
Amikasin & 21 & 30,0 \\
Piperasilin/tazobaktam & 10 & 14,3 \\
Vankomisin & 10 & 14,3 \\
Gentamisin & 4 & 5,7 \\
Metronidazol & 3 & 4,3 \\
Sefiksim & 1 & 1,4 \\
\hline
\end{tabular}

Hasil penelitian ini menunjukkan bahwa waktu pemberian antibiotik pertama kali pada subyek adalah sebelum pengambilan darah sebesar $57,1 \%$, sedangkan sesudah uji sensitifitas hanya sebesar 7,1\%. Tabel 4 menggambarkan lebih rinci waktu pemberian antibiotik pertama kali. 
Tabel 4. Waktu pemberian antibiotik pertama kali

\begin{tabular}{lcc}
\hline \multicolumn{1}{c}{ Waktu pemberian } & Frekuensi & Persentase(\%) \\
\hline Sebelum pengambilan darah & 40 & 57,1 \\
Saat/ Sesudah pengambilan & 25 & 35,7 \\
darah & & \\
Sesudah uji sensitifitas & 5 & 7,1 \\
\hline
\end{tabular}

Setelah adanya hasil uji sensitifitas, subyek mendapatkan antibiotik yang tepat sesuai hasil uji sensitifitas meningkat sebesar 37,2\% dibandingkan sebelum uji sensitifitas. Ketepatan penggunaan antibiotik sebelum uji sensitifitas $27,1 \%$ sedangkan sesudahnya sebesar $64,3 \%$. Rincian distribusi ketepatan penggunaan antibiotik dapat dilihat pada Tabel 5.

Tabel 5. Ketepatan penggunaan antibiotik berdasarkan uji sensitifitas

\begin{tabular}{lcccc}
\hline & \multicolumn{2}{c}{ Sebelum uji sensitifitas } & \multicolumn{2}{c}{ Sesudah uji sensitifitas } \\
& Frekuensi & Persentase(\%) & Frekuensi & Persentase(\%) \\
\hline Tepat & 19 & 27,1 & 45 & 64,3 \\
Tidak tepat & 47 & 67,1 & 12 & 17,1 \\
Tanpa antibiotik & 4 & 5,7 & 13 & 18,6 \\
\hline
\end{tabular}

\section{PEMBAHASAN}

Hasil penelitian ini menunjukkan bahwa lebih dari separuh subyek penelitian adalah sepsis onset dini dan berat badan lahir kurang dari 2500 gram, sedangkan $23,3 \%$ diantara total subyek adalah berat badan lahir sangat rendah (BBLSR). Berat badan lahir kurang ini merupakan faktor risiko minor untuk kejadian sepsis neonatus. ${ }^{13}$

Antibiotik empiris yang banyak diberikan dalam penatalaksanaan pasien ini secara berurutan adalah amikasin, meropenem dan piperasilin/tazobaktam. Sedangkan antibiotik definitif adalah meropenem, amikasin, piperasilin/tazobaktam dan vankomisin. Keseluruhan antibiotik tersebut termasuk antibiotik lini kedua dan ketiga dalam penatalaksanaan sepsis neonatus, sedangkan antibiotik lini pertama yang digunakan pada penelitian ini adalah gentamisin. ${ }^{5}$

Lebih dari separuh pasien sepsis neonatus mendapatkan antibiotik pertama kali sebelum pengambilan darah kultur. Beberapa alasan pemberian antibiotik empiris segera tersebut yaitu hasil kultur darah yang membutuhkan waktu yang cukup lama, mencegah komplikasi dan menurunkan angka mortalitas. Namun pada penelitian ini didapatkan beberapa subyek $(5,7 \%)$ tidak mendapatkan antibiotik empiris sebelum hasil kultur ada, setelah itu mendapatkan antibiotik definitif. Penanganan terhadap kasus sepsis pada neonatus harus cepat dilaksanakan. Penentuan jenis kuman penyebab secara pasti memang diperlukan namun membutuhkan waktu. Pemberian antibiotik empiris perlu segera diberikan bagi pasien sepsis dengan risiko tinggi. ${ }^{5}$ Sedangkan $18,6 \%$ subyek tidak mendapatkan lagi antibiotik setelah hasil kultur darah keluar karena antibiotik empiris sudah diberikan dengan tepat dan lama waktu pemberian antibiotik juga sudah sesuai.

Antibiotik adalah obat yang terbanyak diresepkan di ruang perawatan Perina. Penggunaan antibiotik pada sepsis neonatorum seharusnya didasarkan pada bakteri penyebab infeksi berdasarkan hasil biakan darah dan uji sensitifitas, akan tetapi sampai saat ini pemeriksaan biakan dan uji sensitifitas memerlukan waktu yang lama, sehingga pada kasus tersangka sepsis harus diberikan antibiotik secara empiris. ${ }^{5}$

Berdasarkan berbagai penelitian, beberapa pilihan antibiotik empiris pada pasien sepsis neonatus berdasarkan awitan sepsis dan kuman penyebabnya antara lain untuk sepsis onset dini pilihannya adalah kombinasi Penisilin dan gentamisin. Jika disebabkan Listeria monocytogenes adalah kombinasi amoksisilin dan gentamisin, sedangkan jika disebabkan oleh Stafilococcus aureus pilihannya yaitu kombinasi flukloksasilin dan gentamisin. Sedangkan untuk sepsis onset lambat pilihannya 
adalah lini pertama : kombinasi flukloksasilin dan gentamisin, lini kedua : kombinasi vankomisin dan gentamisin yang pemberiannya harus dengan hatihati, kombinasi vankomisin dan piperasilin/ tazobaktam (Gram-negatif), lini ketiga: meropenem, siprofloksasin. ${ }^{5,14,15}$

Pilihan antibiotik empiris untuk meningitis yaitu lini pertama : kombinasi sefotaksim dengan amoksisilin \pm gentamisin dan lini kedua : meropenem. Untuk kuman Gram positif multiresisten, saat ini terutama menggunakan antibiotik glikopeptida vankomisin, jika diperlukan dapat diberikan antibiotik alternatif yaitu : linezolid, klindamisin, rifampisin dan daptomisin. Pada pemeriksaan Gram negatif multiresisten pilihannya adalah aminoglikosida dan sefalosporin. Alternatif dapat diberikan karbapenem, kolistin, kotrimoxazol, tikarsilin-asam klavulanat. sedangkan fluoroquinolon, siprofloksasin, tigesiklin dan tetrasiklin hanya pada kasus yang ekstrim. ${ }^{5,14,15}$

Setelah hasil uji sensitifitas penggunaan antibiotik yang tepat terjadi peningkatan walaupun belum mencapai $100 \%$ hal ini disebabkan antara lain ada beberapa subyek yang telah mendapatkan antibiotik empiris yang sudah tepat dan kemudian pemberian antibiotik dihentikan.

\section{KESIMPULAN}

Berdasarkan hasil penelitian ini didapatkan kesimpulan bahwa pasien sepsis neonatus yang dirawat di RSUD Arifin Achmad Provinsi Riau terbanyak adalah tergolong onset dini dan berat badan lahir kurang. Antibiotik empiris dan definitif terbanyak digunakan secara berurutan adalah amikasin dan meropenem. Waktu pemberian antibiotik pertama kali terbanyak adalah sebelum pengambilan darah kultur. Pemberian antibiotik definitif yang tidak tepat sebesar $17,1 \%$ serta terjadi peningkatan ketepatan penggunaan antibiotik sesudah uji sensitifitas.

\section{UCAPAN TERIMAKASIH}

Penulis mengucapkan terimakasih kepada Panitia Hibah Peningkatan Akreditasi Prodi S1 Fakultas Kedokteran Universitas Riau yang telah mendanai penelitian ini.

\section{DAFTAR PUSTAKA}

1. Sianturi P, Hasibuan BS, Lubis BM, Azlin Emil, Tjipta GD. Gambaran pola resistensi bakteri di unit perawatan neonatus. Sari Pediatri. 2012;13(6):431-36.

2. World Health Organization. Neonatal and perinatal mortality: Country, Region, and Global Estimates. Geneva Switzerland, World Health Organization. 2006. p.1-27.

3. Pusponegoro TS. Sepsis pada neonatus (Sepsis Neonatal). Sari Pediatri. 2000; 2(2):96-102.

4. Depani SJ, Ladhani S, Heath PT, Lamagni TL, Johnson AP, Pebody RG, et al.The contribution of infections to neonatal deaths in England and Wales. Pediatr Infect Dis J. 2011;30(4):345-7.

5. Tzialla C, Borghesi A, Serra G, Stronati M, Corsello G, Antimicrobial therapy in neonatal intensive care unit. Italian Journal of Pediatrics 2015 41:27.

6. Anderson-Berry AL. Neonatal Sepsis. MedScape [Internet]. 2014 Feb. [cited 24 Mei 2014]. Available from: http:// emedicine.medscape.com/article/978352overview

7. Lissauer T, Arroy. At A Glance Neonatology. Jakarta: Erlangga; 2010

8. Stoll BJ, Hansen NI, Sánchez PG, Faix RG, Poindexter BB, Van Meurs KP, et al. Early onset neonatal sepsis: the burden of group $B$ Streptococcal and E. coli disease continues. Pediatrics. 2011;127(5):817-26

9. Shah Birju A, Padbury James F. Neonatal Sepsis - An old problem with new insights. Virulance [Internet]. 2014 Jan [cited2014 November 9]; 5(1):170-178. Available from: http:// www.ncbi.nlm.nih.gov/pmc/articles/ $\underline{\text { PMC3916371/ }}$

10. Vergnano S, Menson E, Kennea N, Embleton N, Russell AB, Watts T, et al. Neonatal infections in England: the NeonIN surveillance network. Arch Dis Child Fetal Neonatal Ed. 2011;96:F914

11. Shrestha S, Shrestha NC, Dongol SS, Shrestha RP, Kayestha S, Shrestha M, et al. Bacterial isolates and its susceptibility pattern in 
NICU.Kathmandu Univ Med [Internet]. 2013 Jan-Mar [cited2014 Januari 30]; 11 (41):66-70. Available from: http://www.ncbi.nlm.nih.gov/ pubmed/23774417

12. Kosim Sholeh H. Buku Ajar Neonatologi Anak. Edisi Pertama. Jakarta: Ikatan Dokter Anak Indonesia. 2008

13. Wilar Rocky, Kumalasari Ellen, Suryanto DY, Gunawan stefanus. Faktor risiko sepsis awitan dini. Sari Pediatri. 2010;12(4): 265-69.
14. Russell AB, Sharland M, Heath PT. Improving antibiotic prescribing in neonatal units: time to act. Arch Dis Fetal Neonatal. 2012;97:F141-6.

15. Gray JW, Patel M. Management of antibioticresistant infection in the newborn. Arch Dis Child Educ Pract. 2011;96(4):122-7. 